\title{
Ethiopian Community Attitude Towards the 0-Words (Overweight and Obesity); As A Symbol of Wealth, Health, Beauty, Comfort, Honesty, Dignity, Respect And Confidence Which Should Be A Turning Point For Their Detrimental Effects
}

\author{
Wondu Reta Demissie* \\ Department of Biomedical Sciences, Jimma University, Ethiopia \\ *Corresponding author: Wondu Reta Demissie, Department of Biomedical sciences, Jimma University, Institute of Health, Ethiopia. \\ To Cite This Article: Wondu Reta Demissie*. Ethiopian Community Attitude Towards the O-Words (Overweight and Obesity); As A Symbol Of \\ Wealth, Health, Beauty, Comfort, Honesty, Dignity, Respect And Confidence Which Should Be A Turning Point For Their Detrimental Effects. Am \\ J Biomed Sci \& Res. 2019 - 1(4). AJBSR.MS.ID.000536. DOI: 10.34297/AJBSR.2019.01.000536
}

Received: February 21, 2019 | Published: February 26, 2019

\section{Commentary}

Body mass index (BMI) is a simple index of weight-for-height that is commonly used to classify overweight and obesity. It is defined as a person's weight in kilograms divided by the square of his/her height in meters $\left(\mathrm{kg} / \mathrm{m}^{2}\right)$. The WHO definition for a BMI greater than or equal to 25 is overweight and a BMI greater than or equal to 30 is obesity. BMI provides the most useful populationlevel measure of overweight and obesity as it is the same for both sexes and for all ages of adults [1].

The populations residing in the horn of Africa (Ethiopians and Eritreans) were known by famine and drought among the world with low mean body mass index of 15.5 (14.4-16.6) for males; 16.8 (15.6-17.9) for females and 16.8 (15.1-18.6) for males; 17.5 (15.9-19.3) for females respectively [2]. The possible opinions/ justifications for low BMI were not only absence of foods to ingest but also other social, cultural, religious, economic and demographic bases.

Majority of the Ethiopian community were Christians and Muslims who are practicing regular fasting guidelines. Culturally the community doesn't follow regular feeding habits rather give priority for activities. Majority of Ethiopians especially living in rural part of the country eat only twice daily (morning and night). Due to infrastructural limits in the country at large, all most all of the community engaged in strenuous activity forcefully in their daily activity and covering more kilometres on bare foot. This all together results imbalance between energy intake and energy lost physiologically. So, in general due to those reasons it is unlikely to become overweight. Thus, the community gives value to overweight as it is strange and odd among them.

But the life style of the Ethiopian community now a day turned to the global as majority of the population migrated from rural part to urban. Totally the life style of two areas (rural and urban) is completely different and drives the BMI of the community to different wings (underweight and overweight) [3]. Ethiopian community residing in the urban is diffused with globalization and undergoes life modification (eating more than three times especially fat rich foods, unexercised) that enable them overweight and obese [3].

My observation was also supported by statistics as globally the mean BMI worldwide increased by $0.4 \mathrm{~kg} / \mathrm{m} 2$ per decade $(95 \%$ uncertainty interval $0.2-0.6$ ) for men and $0.5 \mathrm{~kg} / \mathrm{m} 2$ per decade $(0.3-0.7)$ for women between 1980 and 2008. In general, the mean BMI has increased since 1980 globally though the trends varies between nations which needs due emphasis that can curb or reverse the increase, and mitigate the health effects of high BMI [4,5]. In 1975, age-standardized mean BMI for Ethiopians was less than $19 \mathrm{~kg} / \mathrm{m}^{2}$ but increased to more than $20.0 \mathrm{~kg} / \mathrm{m}^{2}$ in men and more than $20.7 \mathrm{~kg} / \mathrm{m}^{2}$ in women in 2014 [6].

I have got the access of observing the attitude of Ethiopian community living in every corner of the country perceiving o-words (overweight and obesity) as symbol of wealth, health, beauty, comfort, honesty, dignity, respect and confidence despite a few literate community dislikes for their detrimental effect. 
Ethiopian community was not only unique, but there are also other communities who admit overweight and obesity positively. For instance, urban black community in a South Africa prefer a moderately overweight shape (BMI $27 \mathrm{~kg} / \mathrm{m}^{2}$ ) and associated it with dignity, respect, confidence, beauty, and wealth [7]. The study conducted among Chinese community reported that underweight among men was associated with depressive symptoms and overweight was preferred [8]. The other study conducted among different communities reported possible attitudes as: Cameroon community living both in urban and rural parts believed 'Fatness is prestige' and assumed that fat people have no worries, have peace of mind, have good jobs and have healthy children who do well in school or in their occupation; Weight gain, after marriage among Indian was seen as natural and as a sign of happiness; but in contrast to that Australian community responded as people became overweight/obese because they had no willpower, couldn't discipline themselves, did not work hard, were lazy and/or hopeless [9]. The other wing of study conducted among American community and even among health care professions showed their attitude towards obesity as "weak-willed, ugly, awkward, lazy, dirty, stupid, cheats, and liars" [10].

The book entitled 'fat politics' written in America expressed obesity and excess weight as they caused 400000 extra deaths annually among Americans and but also actually, being slightly overweight rather than normal weight predicted better adult health. Negative attitudes toward overweight people contribute to the obesity epidemic. More than half of the public are stigmatized as suffering from the disease of overweight, and there are costs associated with dangerous diet pills and faulty surgeries [11].

Currently beside communities' attitude, obesity is determined as the cause of morbidity and mortality for different diseases like cardiovascular diseases, diabetes, hypertension, hypercholesterolemia, orthopaedic disorders, malignancies/ cancers of cardiovascular and kidney diseases, and musculoskeletal disorders [12-16].

Thirty years ago international nutritionists were focusing on childhood malnutrition, the 'protein gap' and how to feed the world's burgeoning population, and medical services in the developing world were concentrated on the fight against infectious diseases but today the World Health Organization finds itself needing to deal with the new pandemic of obesity and its accompanying noncommunicable diseases (NCDs) [17].

Currently there are numerous medias and papers that focusing on the obese and overweight to address the broader social and economic issues that influence people's lives and discusses strategies to remove from a focus on the O-word [18,19]. Thus, I recommend my community to turn point their attitude towards o-words as more detrimental than positives.

\section{References}

1. World Health Organization (1995) Physical status: The use of and interpretation of anthropometry, Report of a WHO Expert Committee.
2. Country Prevalence - Mean BMI, BMI, Data Visualisations, NCD-RisC

3. Neuman M, Kawachi I, Gortmaker S, Subramanian SV (2013) Urbanrural differences in BMI in low-and middle-income countries: the role of socioeconomic status. Am J Clin Nutr 97(2): 428-436.

4. Finucane MM, Stevens GA, Cowan MJ, Danaei G, Lin JK, et al. (2011) National, regional, and global trends in body-mass index since 1980: systematic analysis of health examination surveys and epidemiological studies with 960 country-years and 9.1 million participants. Lancet 377(9765): 557-567.

5. Abarca Gómez L, Abdeen ZA, Hamid ZA, Abu Rmeileh NM, Acosta Cazares $\mathrm{B}$, et al. (2017) Worldwide trends in body-mass index, underweight, overweight, and obesity from 1975 to 2016: a pooled analysis of 2416 population-based measurement studies in 128.9 million children, adolescents, and adults. Lancet 390(10113): 2627-2642.

6. Mariachiara Di Cesare, James Bentham, Gretchen A Stevens, Bin Zhou, Goodarz Danaei, et al. (2016) Trends in adult body-mass index in 200 countries from 1975 to 2014: A pooled analysis of 1698 populationbased measurement studies with 19.2 million participants. The Lancet 387(10026): 1377-96.

7. Puoane T, Fourie JM, Shapiro M, Rosling L, Tshaka NC, et al. (2016) Big is beautiful-an exploration with urban black community health workers in a South African township. South Afr J Clin Nutr 18(1): 6-15.

8. Yu NW, Chen CY, Liu CY, Chau YL, Chang CM (2011) Association of body mass index and depressive symptoms in a Chinese community population: results from the Health Promotion Knowledge, Attitudes, and Performance Survey in Taiwan. Chang Gung Med J 34(6): 620-627.

9. Treloar C, Porteous J, Hassan F, Kasniyah N, Lakshmanudu M, et al. (1999) The cross cultural context of obesity: an INCLEN multicentre collaborative study. Health Place 5(4): 279-286.

10. Van Itallie TB (1985) Health implications of overweight and obesity in the United States. Ann Intern Med 103(6_Part_2): 983-988.

11. Oliver JE (2006) Fat politics: the real story behind America's obesity epidemic. Oxford University Press New York, pp. 240.

12. Berrington de Gonzalez A, Hartge P, Cerhan JR, Flint AJ, Hannan L, MacInnis RJ, et al. (2010) Body-mass index and mortality among 1.46 million white adults. N Engl J Med 363(23): 2211-2219.

13. Prospective Studies Collaboration, Whitlock G, Lewington S, Sherliker $P$, Clarke R, Emberson J, et al. (2009) Body-mass index and cause-specific mortality in 900000 adults: collaborative analyses of 57 prospective studies. Lancet 373(9669): 1083-1096.

14. Djalalinia S, Qorbani M, Peykari N, Kelishadi R (2015) Health impacts of obesity. Pak J Med Sci 31(1): 239.

15. Lu Y, Hajifathalian K, Ezzati M, Woodward M, Rimm EB, et al. (2014) Metabolic mediators of the effects of body-mass index, overweight, and obesity on coronary heart disease and stroke: a pooled analysis of 97 prospective cohorts with $1 \cdot 8$ million participants. Lancet 383(9921): 970-83.

16. Singh GM, Danaei G, Farzadfar F, Stevens GA, Woodward M, et al. (2013) The age-specific quantitative effects of metabolic risk factors on cardiovascular diseases and diabetes: a pooled analysis. PloS One 8(7): e65174.

17. Prentice AM (2005) The emerging epidemic of obesity in developing countries. Int J Epidemiol 35(1): 93-99.

18. Cohen L, Perales DP, Steadman C (2005) The O word: why the focus on obesity is harmful to community health. Californian J Health Promot 3(3): 154-161.

19. Thomas S, Hyde J, Komesaroff P (2007) Cheapening the struggle: Obese people's attitudes towards The Biggest Loser. Obesity Management 3(5): 210-215. 